\title{
Subnormothermic Perfusion in the Isolated Rat Liver Preserves the Antioxidant Glutathione and Enhances the Function of the Ubiquitin Proteasome System
}

\author{
Teresa Carbonell, ${ }^{1}$ Norma Alva, ${ }^{1}$ Sergio Sanchez-Nuño, ${ }^{1}$ \\ Shannamar Dewey, ${ }^{2}$ and Aldrin V. Gomes ${ }^{2}$ \\ ${ }^{1}$ Department of Cell Biology, Physiology and Immunology, University of Barcelona, Avda Diagonal 643, 08028 Barcelona, Spain \\ ${ }^{2}$ Department of Physiology, Neurobiology and Behavior, University of California, Davis, 176 Briggs Hall, One Shields Avenue, \\ Davis, CA 95616, USA \\ Correspondence should be addressed to Teresa Carbonell; tcarbonell@ub.edu
}

Received 13 July 2016; Revised 9 September 2016; Accepted 15 September 2016

Academic Editor: Ruchi Shah

Copyright ( 2016 Teresa Carbonell et al. This is an open access article distributed under the Creative Commons Attribution License, which permits unrestricted use, distribution, and reproduction in any medium, provided the original work is properly cited.

The reduction of oxidative stress is suggested to be one of the main mechanisms to explain the benefits of subnormothermic perfusion against ischemic liver damage. In this study we investigated the early cellular mechanisms induced in isolated rat livers after $15 \mathrm{~min}$ perfusion at temperatures ranging from normothermia $\left(37^{\circ} \mathrm{C}\right)$ to subnormothermia $\left(26^{\circ} \mathrm{C}\right.$ and $\left.22^{\circ} \mathrm{C}\right)$. Subnormothermic perfusion was found to maintain hepatic viability. Perfusion at $22^{\circ} \mathrm{C}$ raised reduced glutathione levels and the activity of glutathione reductase; however, lipid and protein oxidation still occurred as determined by malondialdehyde, 4-hydroxynonenal-protein adducts, and advanced oxidation protein products. In livers perfused at $22^{\circ} \mathrm{C}$ the lysosomal and ubiquitin proteasome system (UPS) were both activated. The $26 \mathrm{~S}$ chymotrypsin-like $(\beta 5)$ proteasome activity was significantly increased in the $26^{\circ} \mathrm{C}(46 \%)$ and $22^{\circ} \mathrm{C}(42 \%)$ groups. The increased proteasome activity may be due to increased Rpt6 Ser120 phosphorylation, which is known to enhance $26 \mathrm{~S}$ proteasome activity. Together, our results indicate that the early events produced by subnormothermic perfusion in the liver can induce oxidative stress concomitantly with antioxidant glutathione preservation and enhanced function of the lysosomal and UPS systems. Thus, a brief hypothermia could trigger antioxidant mechanisms and may be functioning as a preconditioning stimulus.

\section{Introduction}

A major clinical problem in liver surgery and transplantation is damage due to transient ischemia and reperfusion [13]. The pathological process involves a variety of cellular dysfunctions caused by increased production of reactive oxygen species and inflammatory responses [4]. Several studies suggest that the induction of mild $\left(32-35^{\circ} \mathrm{C}\right)$ to moderate $\left(28-32^{\circ} \mathrm{C}\right)$ hypothermia may attenuate the progression of liver damage against ischemia $[1,5,6]$. Moreover, perfusion in ex vivo machines resulted in improved viability at subnormothermic temperatures $\left(20-21^{\circ} \mathrm{C}\right)$, in both livers from experimental animals [7-11] and from humans $[12,13]$. These authors also found that many livers which would be discarded due to their low quality could be rescued for transplantation thanks to the restorative effects of subnormothermic perfusion.

There is growing interest in the use of hypothermia to prevent ischemic damage in clinical and experimental trials [14]. The protective effects of hypothermia are suggested to primarily be a consequence of decreased cellular metabolism, thus conserving ATP levels [15]. This proposal implies a passive method for hypothermia-induced protection and does not explain the wide role of therapeutic hypothermia against many injuries and in different tissues. Reduction of oxidative stress, as observed in ischemic cardiomyocytes 
[16], and attenuation in the consumption of endogenous antioxidants, as seen in hypoxic brains $[17,18]$, could be two additional mechanisms.

In the liver, the observed hepatoprotective effects of hypothermia against ischemia include prolonging survival, attenuation of liver damage $[1,5]$, suppressed reactive oxygen species, and improved sinusoidal perfusion [19, 20]. Mild hypothermia also attenuated the progression of liver injury induced by other agents, such as acetaminophen in mice [21] and hepatocarcinogenesis in rats [22].

Cellular pathways affected by hypothermia have been reviewed by our group and others [23-25]. Most of the studies cited in these reviews focused on mechanisms related to inflammation, free radicals, or apoptosis, and consistently demonstrated that when hypothermia is induced before ischemic, hypoxic, or toxic episodes, it is able to reduce deleterious pathways while enhancing protective events.

These effects of hypothermia lead us to consider whether hypothermia could have a more active role in preventing damage through triggering antioxidative mechanisms of cell protection. Given the recent contributions that perfusion of isolated livers at subnormothermic temperature protects cellular integrity $[9,12]$, we investigated isolated perfused rat livers (IPRL) at a range of temperatures from normothermia $\left(37^{\circ} \mathrm{C}\right)$ to subnormothermia $\left(26^{\circ} \mathrm{C}\right.$ and $\left.22^{\circ} \mathrm{C}\right)$ for a brief period of time ( 15 minutes) and then investigated oxidative damage parameters and antioxidant defenses. Jung et al. [26] identified three lines of defense against oxidative stress: the first includes antioxidant molecules (such as glutathione), the second includes enzymatic antioxidants, and the third involves repair system proteins, including the proteolytic pathways. Of the two systems of intracellular proteolysis, the lysosomal system plays an important role in the degradation of membrane-bound proteins while the ubiquitin proteasome system (UPS) is widely recognized as the main system for degradation of cytosolic proteins [27, 28]. Our results suggest hypothermia limits ischemic damage by activating protective mechanisms in two of the oxidative stress defensive categories: antioxidant molecules and repair system proteins. We detected increased glutathione levels and proteolytic activity which may limit ischemia induced oxidative damage.

\section{Materials and Methods}

2.1. Animals and Liver Isolation and Perfusion. Adult male Sprague-Dawley rats (225-250 g body weight) were used in this study. Rats were fasted overnight and had free access to water. Rats were anesthetized with i.p. sodium pentobarbital $(65 \mathrm{mg} / \mathrm{Kg})$. Heart failure was induced by incision in the diaphragm and the liver was isolated and connected for perfusion in a nonrecirculating IPRL system at a flow rate of $3 \mathrm{~mL} / \mathrm{min} / \mathrm{g}$ liver with Krebs-Henseleit buffer (KHB) (mM): $118 \mathrm{NaCl}, 4.7 \mathrm{KCl}, 1.2 \mathrm{MgSO}_{4}, 1.2 \mathrm{KH}_{2} \mathrm{PO}_{4}, 2.5 \mathrm{CaCl}_{2}, 25$ $\mathrm{NaHCO}_{3}, 20$ Hepes (pH 7.4), aerated with $95 \% \mathrm{O}_{2}$, and 5\% $\mathrm{CO}_{2}$ [29]. The procedure was approved by the University of Barcelona Institutional Committee of Animal Care and Research and followed European Community guidelines.

Livers were perfused at $37^{\circ} \mathrm{C}$ for $15 \mathrm{~min}$ to stabilize. Then they were randomly distributed in the three experimental groups that were perfused at $37^{\circ} \mathrm{C}, 26^{\circ} \mathrm{C}$, or $22^{\circ} \mathrm{C}$ for $15 \mathrm{~min}$ (total time of experiment lasting $30 \mathrm{~min}$ ). As an index of cellular injury, plasma alanine aminotransferase (ALT) was measured in the effluent using a commercial kit (BioSystems, Barcelona, Spain). After perfusion, livers were frozen in liquid nitrogen and stored at $-80^{\circ} \mathrm{C}$ until analysis.

Nitric oxide (NO) regulates the hepatic microvascular perfusion through its vasodilatory effect and through its anti-inflammatory actions [30]. NO levels were measured as nitrate plus nitrite in liver homogenates in $10 \%(\mathrm{w} / \mathrm{v})$ PBS, centrifuged at $2000 \times \mathrm{g}$ for $5 \mathrm{~min}$, and ultrafiltered by means of a $30 \mathrm{kDa}$ molecular weight cut-off filter. In the assay, nitrate was converted to nitrite using nitrate reductase and total nitrite was measured using the Griess reaction and a colorimetric assay kit (Cayman Chemical Co., Ann Arbor, MI, USA) and expressed as nmol/mg protein.

All other chemicals were purchased from Sigma-Aldrich Chemical.

2.2. Oxidant Assays. Lipid peroxidation in the liver was determined as the end product malondialdehyde (MDA) by thiobarbituric reactive substances (TBARS) assay [31]. Liver was homogenized with a teflon bar in $10 \%(\mathrm{w} / \mathrm{v})$ RIPA solution, (Tris $50 \mathrm{mM}$ pH 7.4, 1\% Triton X-100, $\mathrm{NaCl}$ $150 \mathrm{mM}$, NaF $5 \mathrm{mM}, 0.1 \%$ sodium dodecyl sulphate, and $1 \%$ sodium deoxycholate) with antiprotease solution (aprotinin at $1.7 \mathrm{mg} / \mathrm{mL}, 2 \mu \mathrm{g} / \mathrm{mL}$ pepstatin, $2 \mu \mathrm{g} / \mathrm{mL}$ leupeptin and $1 \mathrm{mM}$ phenylmethylsulfonyl fluoride, and sodium orthovanadate at $1 \mathrm{mM})$. The suspension was centrifuged at $2000 \times \mathrm{g}$ for $5 \mathrm{~min}$ and the pellet discarded. The formation of MDA-TBA adduct was fluorometrically measured at an excitation wavelength of $515 \mathrm{~nm}$ and an emission wavelength of $550 \mathrm{~nm}$. The calibration curve was determined using tetraethoxypropane. Values are expressed as TBARS in nmol/mg protein.

Advanced oxidation protein products (AOPP) have been identified as a biomarker of oxidative damage to proteins, detecting dityrosine-containing and cross-linking protein products, but also a novel mediator of inflammation [32]. AOPP in liver homogenates were assayed by a modification of Witko-Sarsat's method [32, 33]. The formation of AOPP was spectrophotometrically measured at $340 \mathrm{~nm}$ and results were obtained through a standard calibration curve using $100 \mu \mathrm{L}$ of chloramine-T solution $(0-100 \mu \mathrm{mol} / \mathrm{L})$. AOPP concentration was expressed as $\mu \mathrm{mol} / \mathrm{L}$ of chloramine-T equivalents.

2.3. Total Protein Determination. The total liver proteins were determined using the Bradford protein assay [34].

2.4. Antioxidant Assays. Reduced (GSH) and oxidized glutathione (GSSG) were measured in the liver extracts using the procedure described by Hissin and Hilf [35] and modified by Alva et al. [36]. Tissue was homogenized in cold buffer containing $5 \mathrm{~mm}$ phosphate-EDTA buffer ( $\mathrm{pH} \mathrm{8.0)}$ and $25 \%$ $\mathrm{HPO}_{3}$. The homogenates were ultracentrifuged at $100,000 \times \mathrm{g}$ and $4^{\circ} \mathrm{C}$ for $30 \mathrm{~min}$, and the resulting supernatant was used to determine GSH and GSSG concentrations, using the fluorescent probe $o$-phthalaldehyde. Fluorescence was determined at a wavelength emission of $420 \mathrm{~nm}$ and excitation at $350 \mathrm{~nm}$. 
Glutathione reductase (GSH-R, EC 1.6.4.2) is a flavoprotein that catalyzes the NADPH-dependent reduction of oxidized glutathione (GSSG) to reduced glutathione (GSH). For GSH-R determination, tissue was homogenized in cold buffer (50 mM potassium phosphate, $\mathrm{pH} 7.5,1 \mathrm{mM}$ EDTA) and centrifuged at $10,000 \times \mathrm{g}$ for $15 \mathrm{~min}\left(4^{\circ} \mathrm{C}\right)$. The resulting supernatant was used to measure GSH-R activity with Cayman Chemical Glutathione Reductase Assay Kit (Cayman Chemical Co., Ann Arbor, MI, USA) by measuring the rate of NADPH oxidation. The oxidation of NADPH to NADP+ is accompanied by a decrease in absorbance at $340 \mathrm{~nm}$. Results of GSH-R activity are expressed as $\mathrm{mU} / \mathrm{mg}$ protein.

2.5. Proteolytic Activity Measurement of Cathepsin B and Cathepsin L and $26 S$ Proteasome. Proteolytic activities were measured as previously described by our laboratory [3739]. Cathepsin B and Cathepsin L assays were carried out in a total volume of $100 \mu \mathrm{L}$ per well in black 96-well plates. For the cathepsin B activity, protein samples $(25 \mu \mathrm{g})$ were incubated with $100 \mu \mathrm{M}$ substrate Z-Arg-Arg-AMC (Biomol) in $44 \mathrm{mM}$ potassium phosphate buffer, $6 \mathrm{mM}$ sodium phosphate, $0.67 \mathrm{mM}$ EDTA, and $1.35 \mathrm{mM}$ cysteine (pH 6.0). For cathepsin L activity, protein samples $(25 \mu \mathrm{g})$ were incubated with $100 \mu \mathrm{M}$ substrate Z-Phe-Arg-AMC (Peptides International, Louisville, KY, USA) in $100 \mathrm{mM}$ sodium acetate buffer, with $1 \mathrm{mM}$ EDTA and $1 \mathrm{mM}$ DTT (pH 5.5). The assay was conducted in the absence and presence of a specific inhibitor to determine specific activity: for cathepsin B, $10 \mu \mathrm{M}$ CA074 (Enzo, Life Sciences, Farmingdale, NY, USA) was used, and to inhibit cathepsin L, $10 \mu \mathrm{M}$ Cathepsin L inhibitor I (Calbiochem, La Jolla, CA, USA) was used. Released AMC was measured using a Fluoroskan Ascent fluorometer (Thermo Electron) at $390 \mathrm{~nm}$ (excitation wavelength) and $460 \mathrm{~nm}$ (emission wavelength) for up to $120 \mathrm{~min}$.

The ATP-dependent $26 \mathrm{~S}$ proteasome activities were measured in the presence of $0.1 \mathrm{mM}$ ATP [40]. Liver cell lysates were prepared by homogenization in $50 \mathrm{mM}$ Tris, $1 \mathrm{mM}$ EDTA, $5 \mathrm{mM} \mathrm{MgCl}_{2}, 150 \mathrm{mM} \mathrm{NaCl}$, and $1 \mathrm{mM}$ DTT, pH 7.5. The samples were then centrifuged at $12,000 \times \mathrm{g}$ for $15 \mathrm{~min}$ $\left(4^{\circ} \mathrm{C}\right)$ and the supernatants were collected. To analyze the $26 \mathrm{~S}$ proteasome activity of liver homogenates ( $24 \mu \mathrm{g} / \mathrm{sample})$, the fluorescent substrates Z-LLE-AMC $100 \mu \mathrm{M}$ for $\beta 1$, BocLSTR-AMC for $\beta 2$, and Suc-LLVY-AMC $100 \mu \mathrm{M}$ for $\beta 5$ were used. Each assay was conducted in the absence and presence of a specific proteasome inhibitor Z-Pro-Nle-Asp$\mathrm{H}$ (Enzo) $40 \mu \mathrm{M}$ for $\beta 1$, epoxomicin (Peptides International) $40 \mu \mathrm{M}$ for $\beta 2$, and epoxomicin $10 \mu \mathrm{M}$ for $\beta 5$ to determine proteasome-specific activity. All the assays were carried out in a total volume of $100 \mu \mathrm{L}$. Released AMC was measured using a Fluoroskan Ascent fluorometer (Thermo Electron) at an excitation wavelength of $390 \mathrm{~nm}$ and an emission wavelength of $460 \mathrm{~nm}$.

2.6. Western Blot Analysis and Quantification. Whole liver cell lysates were prepared by homogenizing the livers in: $50 \mathrm{mM}$ Tris (pH 7.5), $1 \mathrm{mM}$ EDTA, $5 \mathrm{mM} \mathrm{MgCl}_{2}, 150 \mathrm{mM}$ $\mathrm{NaCl}$, supplemented with DTT, and protease inhibitors (final concentrations were $10 \mu \mathrm{g} / \mathrm{mL}$ aprotinin, $2 \mu \mathrm{g} / \mathrm{mL}$ pepstatin, $2 \mu \mathrm{g} / \mathrm{mL}$ leupeptin, and $1 \mathrm{mM}$ phenylmethylsulfonyl fluoride). The samples were then centrifuged at $12,000 \times \mathrm{g}$ for $10 \mathrm{~min}$ and the protein concentration measured in the supernatant. Supernatants were treated with Laemmli loading buffer and $50 \mu \mathrm{g}$ of proteins resolved on SDS-polyacrylamide $(10 \%)$ gels and transferred to nitrocellulose. Membranes were then blocked for $1 \mathrm{~h}$ with $3 \%$ nonfat dry milk (NFM) in Trisbuffered saline (TBS) (pH 7.4) containing $0.05 \%(\mathrm{w} / \mathrm{v})$ Tween 20 (TTBS). The membranes were washed three times in TTBS and probed overnight with the following primary antibodies: anti-4-HNE conjugates (Novus Biologicals, Littleton, CO, USA), anti-ubiquitin (Sigma-Aldrich), anti-Rpt6, phospho S120 Rpt6 (affinity purified rabbit antibody commercially made by 21st Century Biochemicals), anti-Rptl, and 20S core subunits ( $\alpha 5 / \alpha 7, \beta 1, \beta 5, \beta 5 \mathrm{i}$, and $\beta 7)$ (Enzo life sciences). Detection was performed with anti-IgG-HRP (Santa Cruz Biotechnology, Inc., Heidelberg, Germany). The blots were visualized with enhanced chemiluminescence (SuperSignal West Pico Chemiluminescent Substrate, Thermo Scientific, Rockford, IL, USA) and detected and scanned on Fujifilm LAS-3000 Imager (Fujifilm Corporation, Tokyo, Japan). Digital images were quantified using Quantity One software (BioRad, Hercules, CA, USA) and normalized to $\beta$-actin (SigmaAldrich, MO, USA). Ponceau S staining as a loading control was used for anti-Rpt6 and phospho S120 Rpt6 western blots due to high protein load $(80 \mu \mathrm{g})$ [41].

2.7. Statistical Analysis. Results are expressed as means \pm SEM of six animals. Data were processed using the statistical software GraphPad InStat (GraphPad Software, Inc., San Diego, CA, USA). The means of the experimental groups were analyzed by two-way ANOVA using the Student-NewmanKeuls test to identify significant differences (when $P<0.05$ ) between the groups.

\section{Results}

3.1. Subnormothermic Perfusion Preserves Liver Function but Increases Oxidative Stress and Protein Oxidation. Our results showed that subnormothermic perfusion preserves liver integrity and function, as reflected by decreased ALT levels in the perfusate (Figure 1(a)), and increased NO in liver (Figure 1(b)). Because NO has an extremely short half-life, we measured it indirectly by quantifying the final products of its reaction, nitrates, and nitrites. These levels increased from $1.48 \pm 0.14$ at $37^{\circ} \mathrm{C}$ to $2.27 \pm 0.17$ at $26^{\circ} \mathrm{C}(P<$ $0.01)$ and $1.945 \pm 0.14$ at $22^{\circ} \mathrm{C}(P<0.05)$. However subnormothermia resulted in higher levels of oxidative stress markers and protein oxidation. One of the effects of oxidative stress is lipid peroxidation which involves the interaction of free radicals with polyunsaturated fatty acids. The end products of lipid peroxidation are reactive aldehydes, such as malondialdehyde (MDA) measured as thiobarbituric reactive substances (TBARS) and 4-hydroxynonenal (HNE). Proteins are particularly susceptible to changes caused by HNE, and HNE-protein adducts formation plays a significant role in many cellular processes [42]. We have found increased levels of TBARS after subnormothermic perfusion at $26^{\circ} \mathrm{C}(P<$ 0.05 ) (Figure 2(a)) and increased HNE-protein adducts at both subnormothermic perfusion temperatures $(P<0.05)$ 


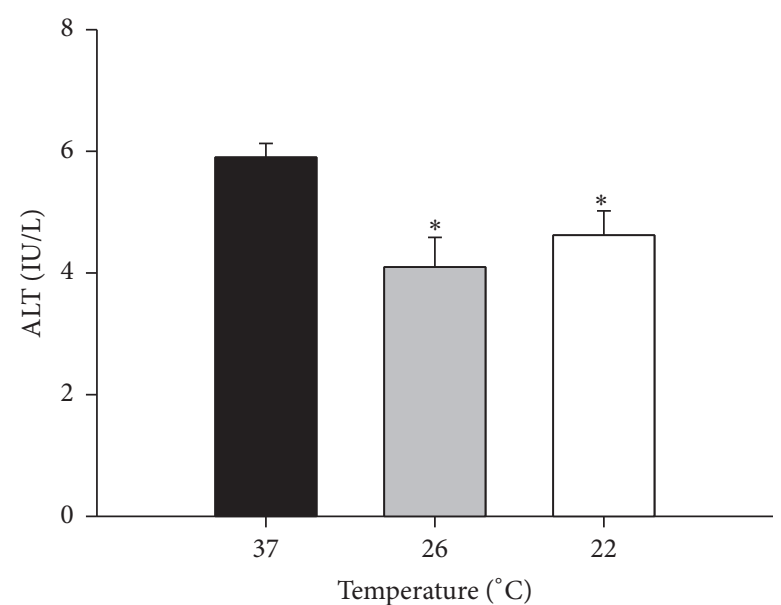

(a)

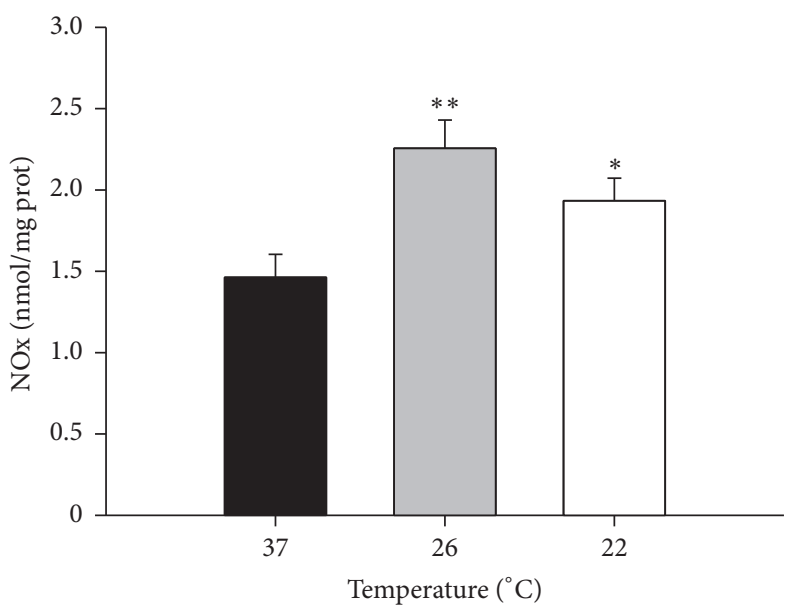

(b)

FIGURE 1: Temperature effects on the hepatic function of isolated perfused rat (IPR) livers. IPR livers were perfused in a nonrecirculating system with Krebs-Henseleit buffer at $37^{\circ} \mathrm{C}$ for $15 \mathrm{~min}$, for stabilization, and then at the indicated temperatures for $15 \mathrm{~min}$ more. Results show cell viability by ALT assay in the perfusate (a) and NO production in liver homogenates (b). Values expressed as mean \pm SEM of $n=6$. Significant differences from livers perfused at $37^{\circ} \mathrm{C}:{ }^{*} \mathrm{P}<0.05$ and ${ }^{* *} \mathrm{P}<0.01$.

(Figure 2(b)). Oxidation induces several modifications in proteins that can lead to new compounds and modified structures. AOPP, which measures dityrosine-containing and cross-linking protein products, increased by $27 \%$ in livers from both subnormothermic perfusion ranges $(P<0.05)$ (Figure 2(c)).

3.2. Subnormothermic Perfusion and Antioxidant Status. Previous results show that the hepatic GSH [36] and the hepatic reduced/oxidized glutathione ratio (GSH/GSSG) increased in hypothermic rats [43] and in ex vivo subnormothermic rat liver [9]. Therefore, we measured the levels of oxidized and reduced glutathione and the activities of the enzyme responsible for the formation of reduced glutathione, glutathione reductase (GSH-R). No differences were observed in GSH levels, GSH/GSSG ratio, and GSH-R activity at $26^{\circ} \mathrm{C}$ (Figures 3(a), 3(b), and 3(c)). However, at $22^{\circ} \mathrm{C} \mathrm{GSH}$ and the GSH/GSSG ratio rised, and the activity of GSH-R increased by $18 \%$.

3.3. Subnormothermic Perfusion Increased the Activity of Cathepsin B and Cathepsin L. The largest group of hydrolases in lysosomal compartments are the cathepsin proteases. Investigation of two cathepsins, B and $\mathrm{L}$, showed that the enzymatic activity of these proteases increased by $26-27 \%$ in subnormothermic livers perfused at $22^{\circ} \mathrm{C}(P<0.05)$ (Figures $4(\mathrm{a})$ and $4(\mathrm{~b}))$ compared to the normothermic group $\left(37^{\circ} \mathrm{C}\right)$ suggesting that the lysosomal activity is increased.

3.4. Subnormothermic Perfusion Increased Ubiquitinated Proteins and the Activity of $26 S$ Proteasomes. Investigation of the three proteolytic activities of the proteasome, the caspaselike $\beta 1$, trypsin-like $\beta 2$, and chymotrypsin-like $\beta 5$ activities, indicated that proteasome activity was increased. While the 26S (ATP-dependent) caspase-like and trypsin-like activities were not significantly affected by the subnormothermic perfusion (Figures 5(a) and 5(b)), the chymotrypsin-like proteasome activity was significantly increased at $26^{\circ} \mathrm{C}(46 \%)$ and at $22^{\circ} \mathrm{C}(42 \%)(P<0.01)$ (Figure $\left.5(\mathrm{c})\right)$. This is especially interesting since the expression of several $20 \mathrm{~S}$ core subunits (Figure 6(b)) and the expression of Rptl ATPase of the $19 \mathrm{~S}$ proteasome subunit (Figure 6(a)) were not affected by subnormothermic perfusion. These results suggest that the increased proteasome activity may be due to posttranslational modifications or changes in the levels of associating partners on the proteasomes rather than its expression. We have previously shown that proteasomes from different tissues have different levels of associating partners which can affect proteasome activity [39].

To determine if the levels of polyubiquitinated proteins are affected by subnormothermic perfusion we utilized western blotting and observed that subnormothermic perfusion resulted in increased levels of polyubiquitinated proteins (Figure 6(c), $P<0.001$ ). Since ubiquitinated proteins are selectively degraded by the $26 \mathrm{~S}$ proteasome and Rpt6 S120 phosphorylation has been shown to increase $26 \mathrm{~S}$ proteasome activity [44], the levels of Rpt6 S120 phosphorylation were investigated. A significant increase in the ratio of phosphoRpt6/Rpt6-ATPase of the $19 S$ proteasome subunit, from $0.59 \pm$ 0.06 at normothermia to $1.06 \pm 0.09(P<0.05)$ at $26^{\circ} \mathrm{C}$ and $1.24 \pm 0.1(P<0.01)$ at $22^{\circ} \mathrm{C}$ (Figure 6(d)), was detected. These results suggest that the increased activity of the proteasome that occurs with subnormothermic perfusion may be due to increased phosphorylation of the serine 120 subunit of Rpt6.

\section{Discussion}

There is widespread consensus that treatment with hypothermia protects against various types of damage in many organs 

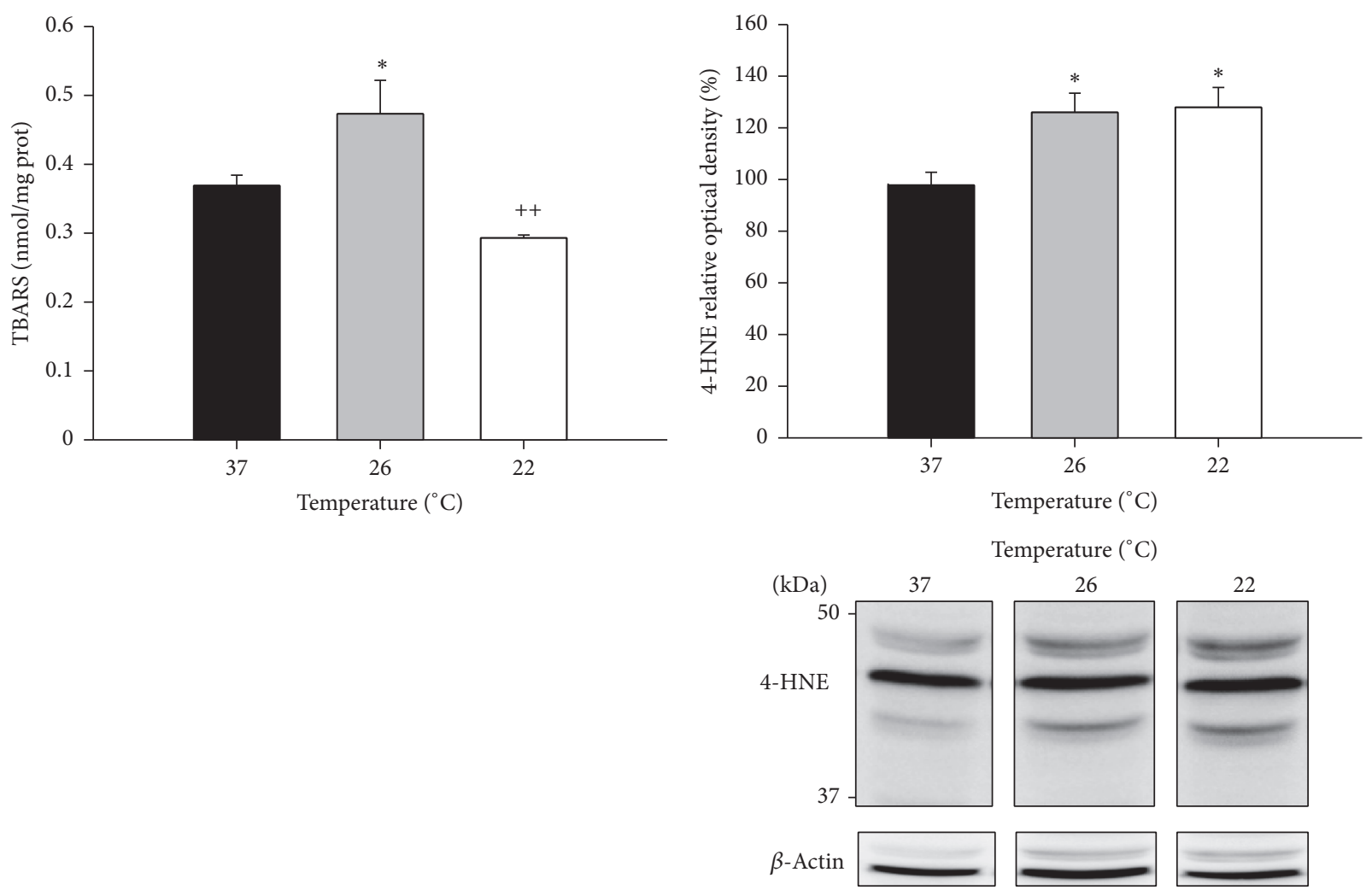

(a)

(b)

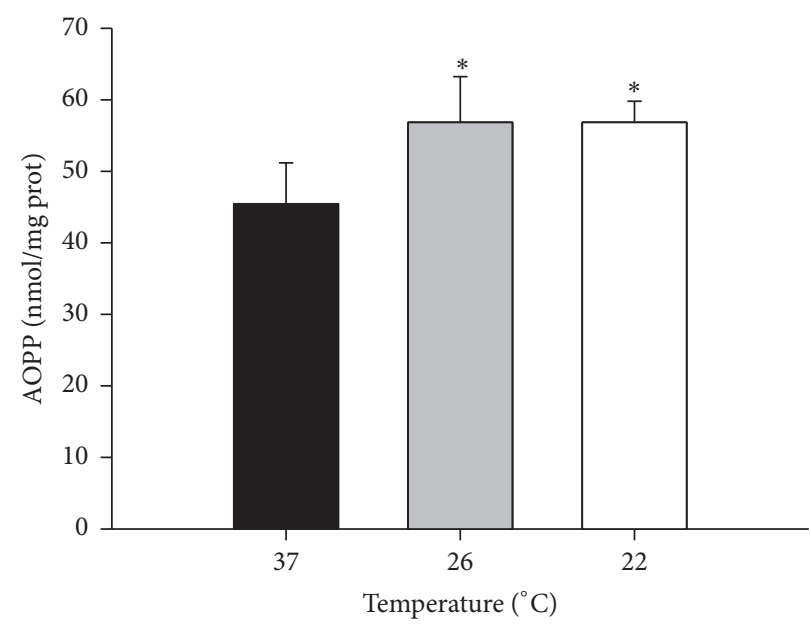

(c)

FIGURE 2: Lipid and protein oxidation in isolated perfused rat livers. IPR livers were perfused in a nonrecirculating system with KrebsHenseleit buffer at $37^{\circ} \mathrm{C}$ for $15 \mathrm{~min}$, for stabilisation, and then at the indicated temperatures for $15 \mathrm{~min}$ more. Lipid peroxidation was measured as TBARS (a) and by western blotting of HNE-protein adducts (b), and advanced oxidation protein products (dityrosine-containing and crosslinking protein products) measured spectrophotometrically at $340 \mathrm{~nm}$ (c). Values expressed as mean \pm SEM of $n=6$. Significant differences from livers perfused at $37^{\circ} \mathrm{C}:{ }^{*} \mathrm{P}<0.05$. Significant differences from livers perfused at $26^{\circ} \mathrm{C}:{ }^{++} \mathrm{P}<0.01$.

[25, 45-47]. Even so, the early events triggered by hypothermic treatment are not yet well defined. Potential mechanisms suggested for such protection include reduction of oxidative stress [16], increased endogenous antioxidants $[17,18]$, reduction of inflammatory mediators [48], and decreased apoptosis [49]. These effects of hypothermia, together with the improved viability seen in subnormothermic perfused livers $[7,9,12]$, lead us to consider whether perfusion at subnormothermic temperatures for a limited period of time could trigger antioxidant mechanisms that confer cellular protection.

The present study demonstrated that liver integrity was retained at subnormothermic temperatures despite increased lipid and protein oxidation levels. Preserved cellular integrity 


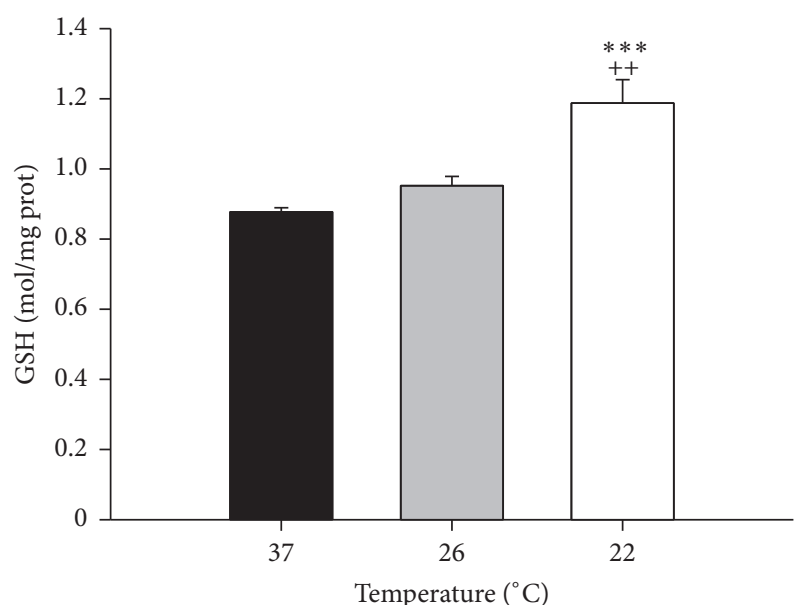

(a)

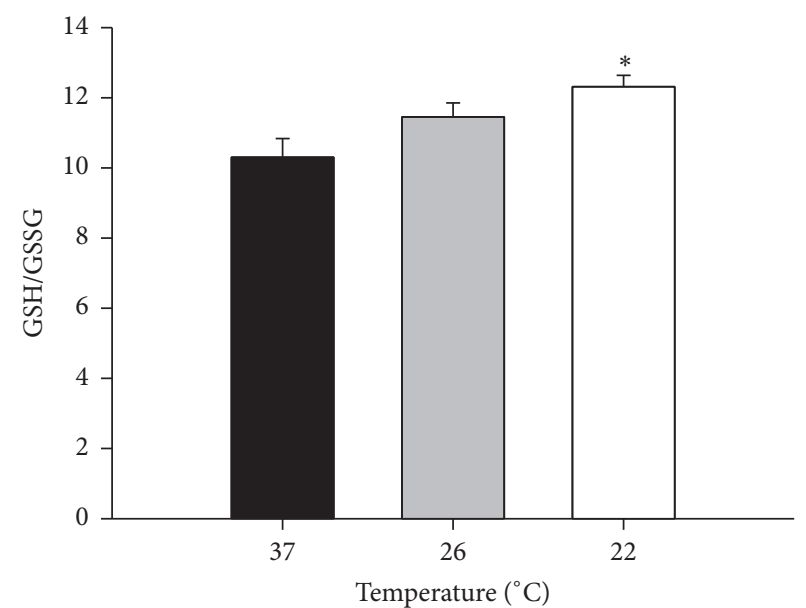

(b)

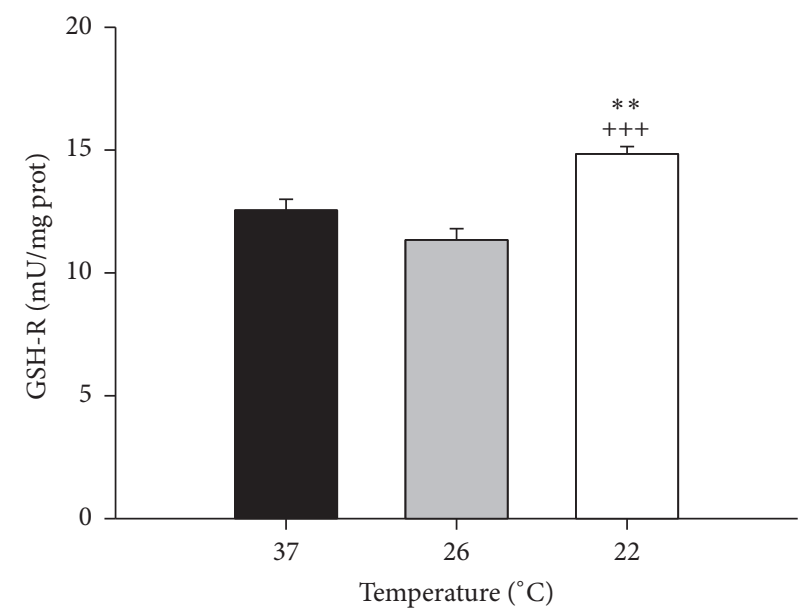

(c)

FIGURE 3: Temperature effects on antioxidant status in isolated perfused rat livers. IPR livers were perfused at $37^{\circ} \mathrm{C}$ for $15 \mathrm{~min}$ and then at the indicated temperatures for 15 min more. Bar graphs show hepatic GSH (a), GSH/GSSG ratio (b), and GSH-reductase activity (c). Values expressed as mean \pm SEM of $n=6$. Significant differences from livers perfused at $37^{\circ} \mathrm{C}:{ }^{*} P<0.05,{ }^{* *} P<0.01$, and ${ }^{* * *} P<0.001$. Significant differences from livers perfused at $26^{\circ} \mathrm{C}:{ }^{++} P<0.01$ and ${ }^{+++} P<0.001$.

was reflected by low ALT levels in the perfusate and increased $\mathrm{NO}$ in the liver. Increased synthesis of NO has been shown to be protective, as it reduces neutrophil adhesion and platelet aggregation while preventing microcirculatory disturbances in liver blood flow $[50,51]$. NO has also been proposed to play a key role in both initiating and mediating ischemic preconditioning [30] and is involved in the preconditioning response for ischemia-reperfusion injury in fatty livers [50,52]. Despite these protective effects, we also measured increased oxidation levels: lipid peroxidation, such as malondialdehyde MDA (measured as TBARS) and protein oxidation (measured by AOPP and HNE-protein adducts) were increased in subnormothermic perfused livers.

Although some results showed that in liver the protein expression of antioxidant enzymes and their activity were relatively unaffected by one hour of cold exposure in rats [53] and in hibernating animals [54], the GSH reductase activity was previously shown to significantly increase after cold exposure in rat livers [55]. Furthermore, the hepatic GSH [36] and reduced/oxidized glutathione ratio (GSH/GSSG) $[9,43]$ were shown to increase after one to six hours at subnormothermic temperature in rats. However, the early effects of brief exposure to subnormothermic temperature on antioxidant enzymes have not been previously reported. In the present work we found increased levels of GSH, the $\mathrm{GSH} / \mathrm{GSSG}$ ratio, and the activity of GSH-R in livers perfused at $22^{\circ} \mathrm{C}$ during $15 \mathrm{~min}$. Although increased levels of GSH and GSH-R activity suggest increased antioxidant capability of the liver, the increased levels of lipid and protein oxidation suggest that the higher antioxidant capacity is at least initially unable to completely prevent lipid peroxidation and the resulting protein damage.

The lipid peroxidation process is a chain reaction that produces multiple breakdown molecules, such as the aldehydes MDA and 4-HNE [56]. 4-HNE appears to be the most toxic product of lipid peroxidation [57]. 4-HNE can 


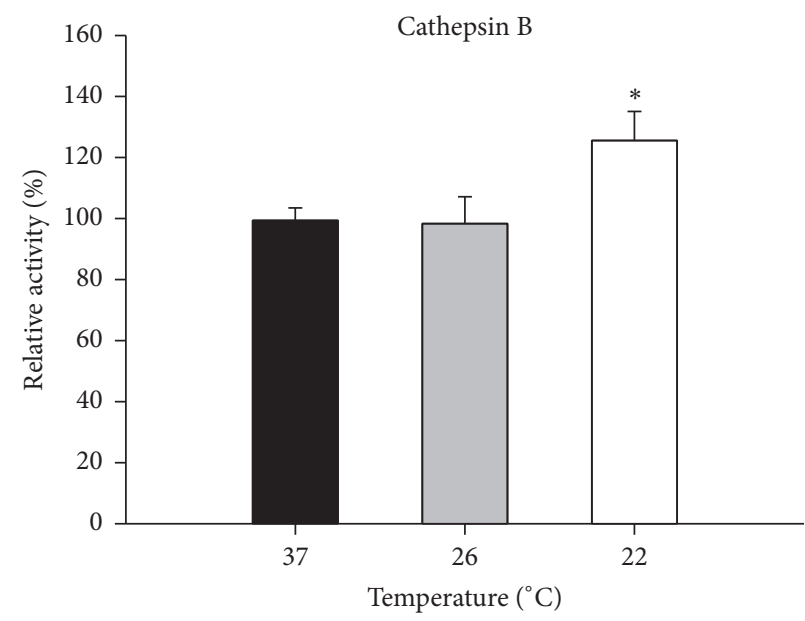

(a)

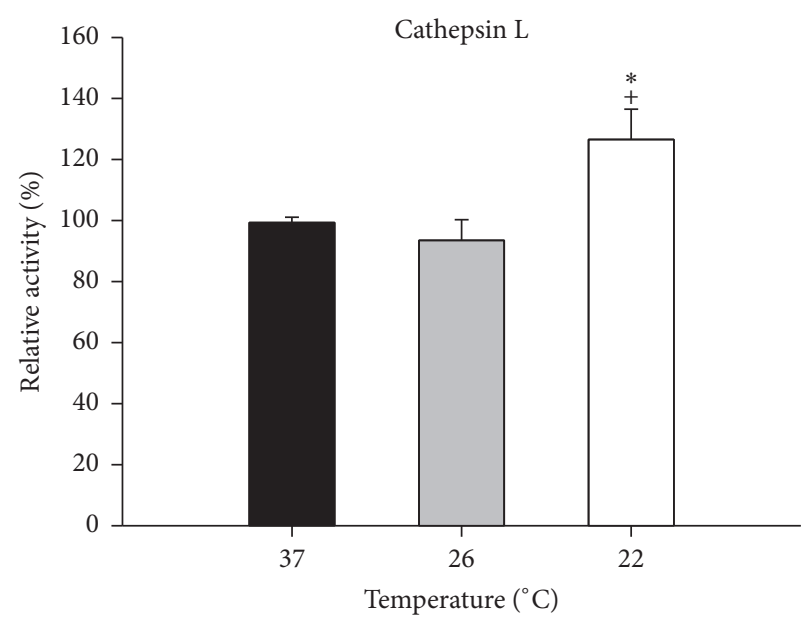

(b)

FIGURE 4: Lysosomal activity in isolated perfused rat livers. IPR livers were perfused at $37^{\circ} \mathrm{C}$ for $15 \mathrm{~min}$ and then at the indicated temperatures for 15 min more. To independent lysosomal enzymes, cathepsin B (a) and cathepsin L (b) were measured to determine if lysosomal activity was affected. Data is expressed as mean \pm SEM of $n=6$. Significant differences from livers perfused at $37^{\circ} \mathrm{C}:{ }^{*} P<0.05$. Significant differences from livers perfused at $26^{\circ} \mathrm{C}:{ }^{+} \mathrm{P}<0.05$.

modify proteins by forming covalent adducts, accelerating protein aggregation [42]. Oxidative modifications of proteins can affect their physiological activity and typically increase their degradation rate. Several reports have highlighted that mild oxidation of proteins increases their susceptibility to proteasomal degradation $[58,59]$. The excessive accumulation of such abnormal proteins can exacerbate the apoptotic or necrotic pathways in the cell [60]. As such, removing abnormal proteins may prevent oxidative stress induced cell death. This function, largely due to the proteasome, has been suggested to be part of the antioxidant defense [26].

The mechanisms by which lipid peroxidation modified proteins are removed from the cell have been studied in different models. 4-HNE exposure increases ubiquitination of adiponectin [61] and the UPS was shown to be the predominant proteolytic enzyme involved in the removal of 4-HNE adducts of alcohol dehydrogenase [62]. In kidney homogenates, HNE-modified proteins were shown to be specifically degraded by the UPS [63]. However, in lens epithelial cells, HNE-modified proteins are ubiquitinated but degraded by the ubiquitin-dependent lysosomal pathway rather than by the proteasome [64]. Moreover, electron micrographs of 4-HNE-treated cells showed extensive vacuolization and treatment with lysosomal inhibitors induced cell death. These findings suggest that lipid peroxidationderived aldehydes also stimulate autophagy [65]. The present study implicates elevated activity in both the UPS and lysosomal pathways.

The lysosome system in the liver is involved in the degradation of membrane-bound or organelle-associated proteins and aggregates. The largest group of hydrolases in lysosomal compartments are the cathepsin proteases, essential for the proteolysis of protein substrates [66]. Cathepsins are responsible for intracellular degradation of Advanced Glycation End
Products- (AGEs-) modified proteins [67] and following oral administration of AGEs, upregulation of cathepsins B and L activities was reported in Drosophila melanogaster [68]. In our model, isolated liver perfusion at $22^{\circ} \mathrm{C}$ (but not at $26^{\circ} \mathrm{C}$ ) resulted in increased activity of the two lysosomal proteases investigated (cathepsins B and L) when compared to control temperatures $\left(37^{\circ} \mathrm{C}\right)$. This increased lysosomal activity may be important in limiting lipid peroxidation damage and removing some of the oxidized proteins (HNE-protein adducts and AOPP). Increased lysosomal activity (lysosomal degradation of autophagosomes) has been shown to protect cardiac myocytes against ischemia/reperfusion injury [69]. Hence it is possible that the increased lysosomal activity at $22^{\circ} \mathrm{C}$ may be protective against ischemia/reperfusion injury.

Oxidized proteins can also be removed by the proteasome $[37,59]$ via ubiquitin independent degradation as well as ubiquitin tagging and subsequent targeting by the $26 \mathrm{~S}$ proteasome [28]. Conversely, it has been suggested that an excess of HNE may directly form adducts on the three proteolytic subunits of the proteasome, thereby reducing its enzymatic activity and contributing to the accumulation of modified proteins [70]. Oxidative damage to various subunits of the $26 \mathrm{~S}$ proteasome during ischemia and reperfusion has also been reported [60]. Seemingly in support of this data, we observed higher levels of polyubiquitinated proteins at $26^{\circ} \mathrm{C}$ and $22^{\circ} \mathrm{C}$ when compared to $37^{\circ} \mathrm{C}$. Similarly, ubiquitin conjugated proteins increased 2-3-fold during torpor in the liver of hibernating squirrels [71].

The intact $26 \mathrm{~S}$ proteasome is composed of one or two $19 S$ regulatory particles at each end of a cylindrical $20 \mathrm{~S}$ core particle. Each protein particle has a complex quaternary structure consisting of many (19-28) subunits. Degradation of protein substrates requires the $19 \mathrm{~S}$ particle to recognize the ubiquitin-conjugated protein and regulate the entry of 


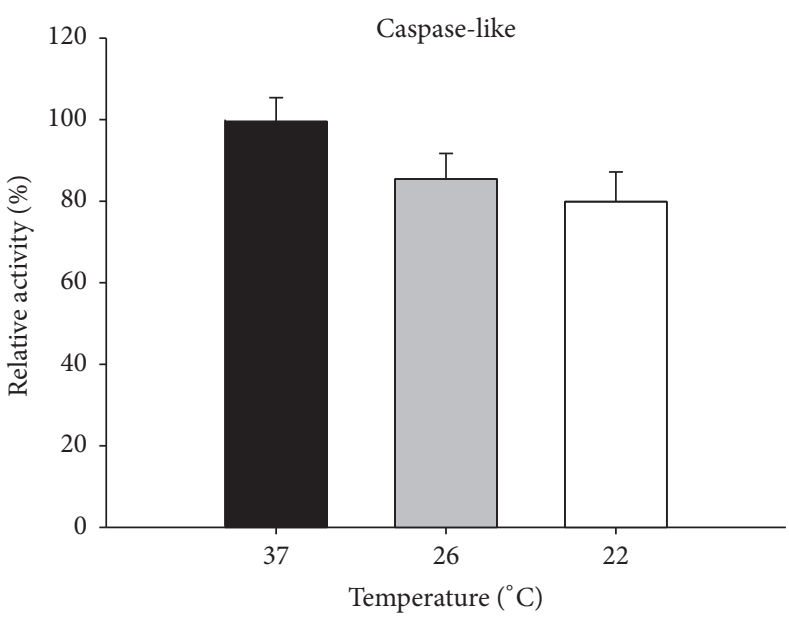

(a)

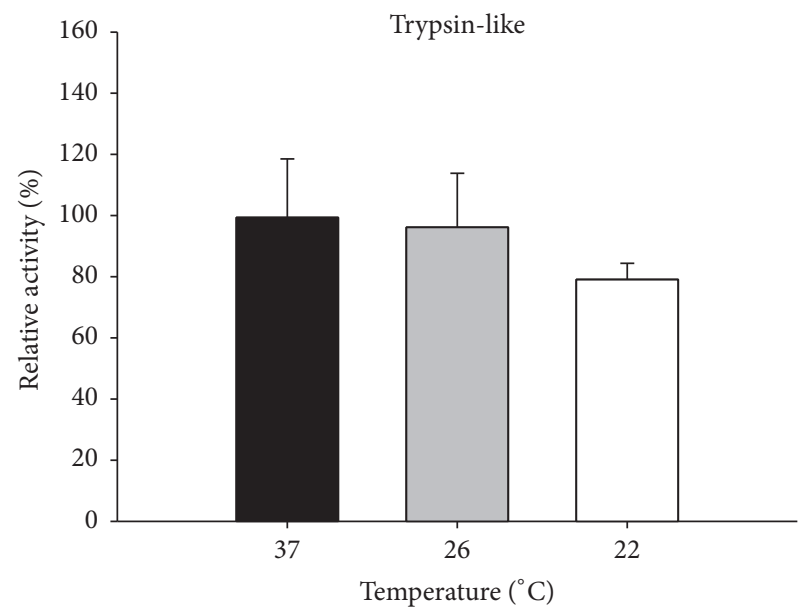

(b)

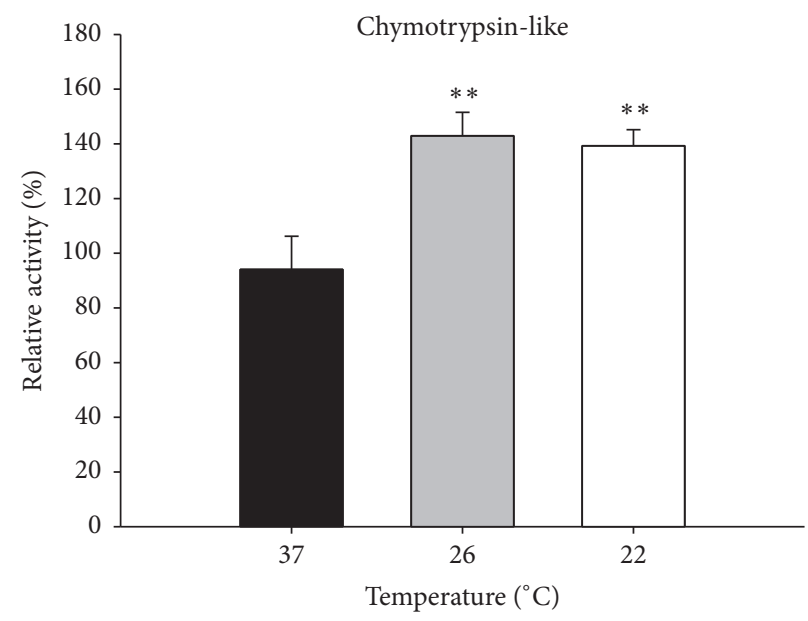

(c)

Figure 5: Proteasomal activity of $26 \mathrm{~S}$ proteasome in isolated perfused rat livers. IPR livers were perfused at $37^{\circ} \mathrm{C}$ for $15 \mathrm{~min}$ and then at the indicated temperatures for 15 min more. The caspase-like $\beta 1$ (a), trypsin-like $\beta 2$ (b), and chymotrypsin-like $\beta 5$ (c) activities of the proteasome were determined. Data is expressed as mean \pm SEM of $n=6$. Significant differences from livers perfused at $37^{\circ} \mathrm{C}:{ }^{* *} P<0.01$.

the substrate in the proteolytic cavity of the $20 \mathrm{~S}$ core particle. The expression of several $20 \mathrm{~S}$ and $19 \mathrm{~S}$ subunits of the proteasome was not affected by subnormothermic temperature in our study, indicating no effect on the number of proteasomes assembled. However, we found a significant increase in the phosphorylation of the 19S subunit Rpt6 at serine 120. Previous studies have revealed that phosphorylation of proteasome subunit Rpt6 increases 26 S proteasome activity and that Rpt6 phosphorylation may be an important regulatory mechanism for proteasome-dependent control [44, 72, 73]. Covalent regulation via phosphorylation allows for a quick increase in the activity of the UPS independent of increasing the overall number of proteasomes. Consistent with an increase in the levels of phosphorylated Rpt6, the 26S chymotrypsinlike activity of the proteasome was significantly increased in livers perfused at both $26^{\circ} \mathrm{C}$ and $22^{\circ} \mathrm{C}$ subnormothermic temperatures. Considering these results and the findings that ischemic preconditioning also enhances proteasome function
[74], it seems probable that the increased proteasome activity is protective. Additionally, elevated proteasome activity has been shown to be associated with long-lived humans (centenarians) [75] and very long-lived animals such as the naked mole rat [76].

\section{Conclusions}

Overall, our results suggest that the early events initiated by hypothermia include the induction of oxidative stress and concurrent stimulation of several potential mechanisms of cell protection, including increased NO and GSH levels and the activation of lysosomal and proteasomal systems to repair oxidative damage. The increased proteasomal activity is likely due, in part, to phosphorylation of serine 120 on the proteasome Rpt6 subunit. Hypothermia may be acting as a preconditioning stimulus which could explain its protective role against ischemic, hypoxic, and toxic damage. 


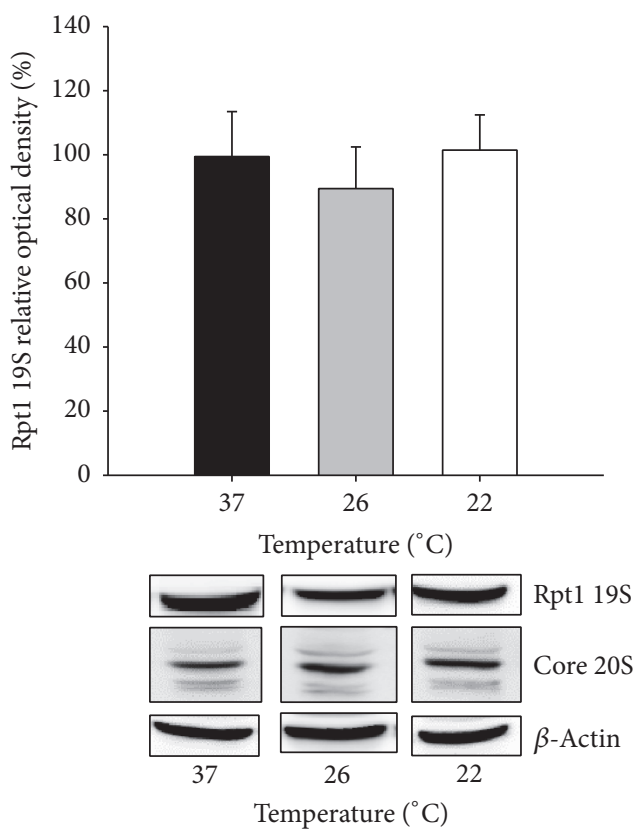

(a)
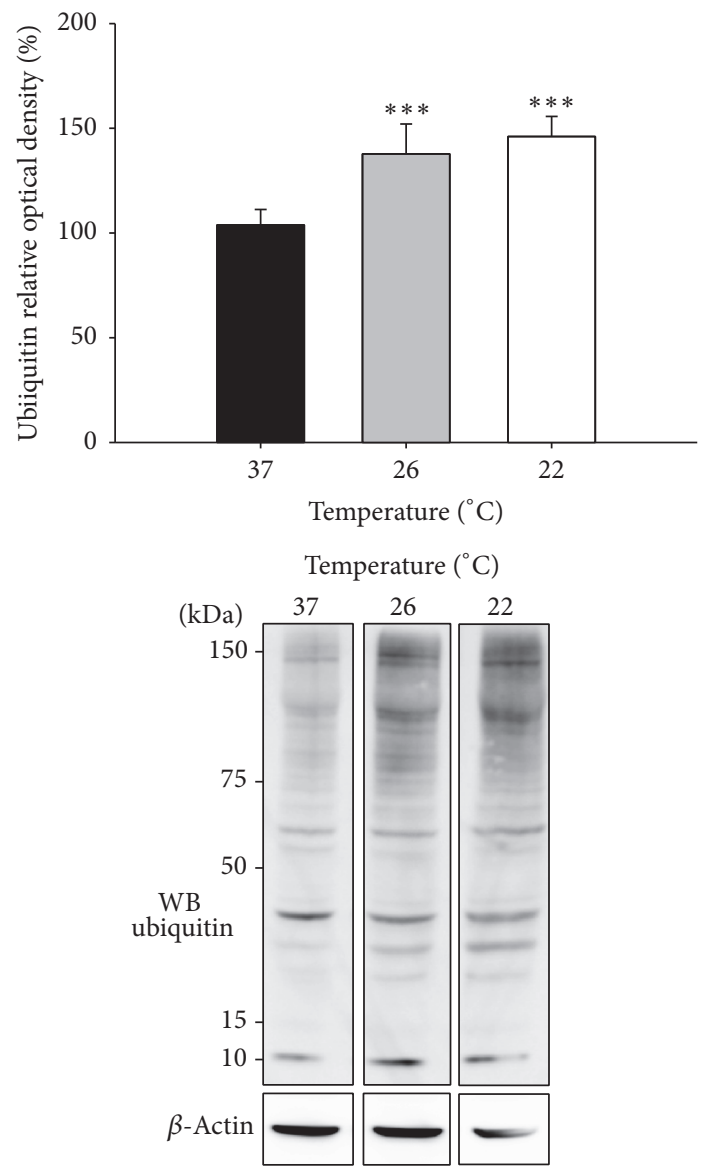

(c)

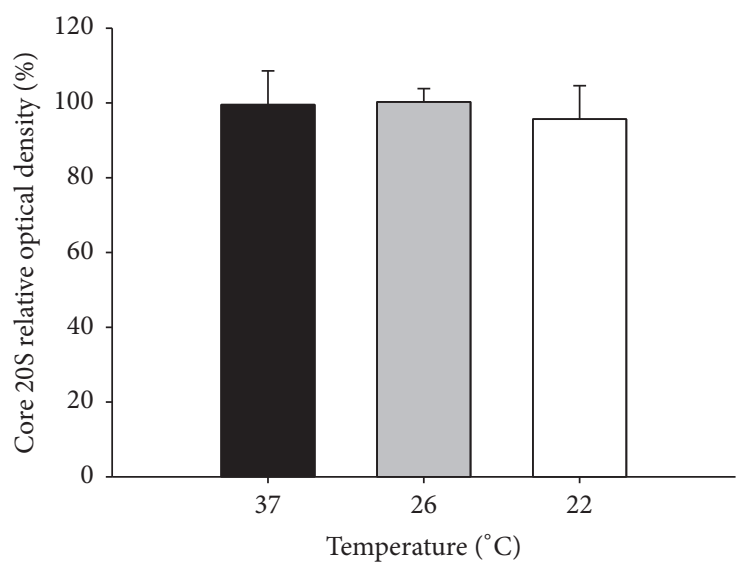

(b)
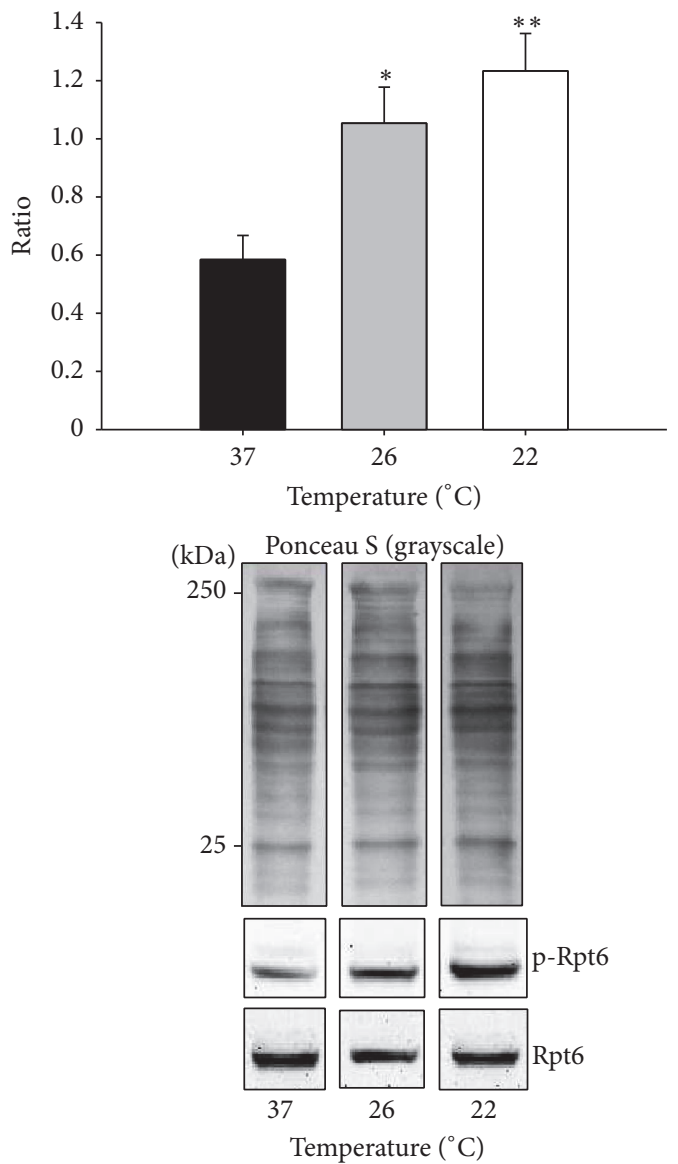

(d)

FIGURE 6: Expression of ubiquitin proteasome system in isolated perfused rat livers. IPR livers were perfused at $37^{\circ} \mathrm{C}$ for $15 \mathrm{~min}$ and then at the indicated temperatures for 15 min more. Results show western blots and densitometric analysis for Rpt1 19S (a) and 20S core subunit (b). (c) Levels of polyubiquitinated proteins; densitometry includes all polyubiquitinated bands detected. $\beta$-Actin was used as a normalization control for the western blots. (d) Ponceau S (total protein) staining was used as loading control for phospho S120 Rpt6 and Rpt6 densitometric analyses of western blots; values were then used to calculate p-Rpt6/Rpt6 ratios. Results are expressed as mean \pm SEM of $n=3$ to 6 independent samples per group. Significant differences from livers perfused at $37^{\circ} \mathrm{C}:{ }^{*} P<0.05,{ }^{* *} P<0.01$, and ${ }^{* * *} P<0.001$. 


\section{Abbreviations}

ALT: Alanine aminotransferase

AOPP: Advanced oxidation protein products

GSH: Reduced glutathione

GSH-R: Glutathione reductase

GSSG: Oxidized glutathione

HNE: 4-Hydroxynonenal

IPRL: Isolated perfused rat livers

MDA: Malondialdehyde

NO: $\quad$ Nitric oxide

TBARS: Thiobarbituric reactive substances

UPS: Ubiquitin proteasome system.

\section{Competing Interests}

The authors declare no competing or financial interests.

\section{Acknowledgments}

This work was financially supported by the Spanish FIS and by ERDF (European Regional Development Fund) PI08-1389 (Teresa Carbonell). Aldrin V. Gomes was supported by a Hellman Fellowship. Shannamar Dewey was partly supported by an American Heart Association Fellowship. Teresa Carbonell participates in the Program of Mobility (PR20090344). The costs of publication of this article have been assumed partly by the Vice-Rector for Science Policy at the University of Barcelona.

\section{References}

[1] K. Nagano, S. Gelman, E. L. Bradley Jr., and D. Parks, "Hypothermia, hepatic oxygen supply-demand, and ischemia-reperfusion injury in pigs," American Journal of Physiology-Gastrointestinal and Liver Physiology, vol. 258, no. 6, pp. G910-G918, 1990.

[2] M. Iñiguex, J. Dotor, E. Feijoo et al., "Novel pharmacologic strategies to protect the liver from ischemia-reperfusion injury," Recent Patents on Cardiovascular Drug Discovery, vol. 3, no. 1, pp. 9-18, 2008.

[3] M. Duval, C. Plin, A. Elimadi et al., "Implication of mitochondrial dysfunction and cell death in cold preservation-warm reperfusion-induced hepatocyte injury," Canadian Journal of Physiology and Pharmacology, vol. 84, no. 5, pp. 547-554, 2006.

[4] A. Alexandrova, L. Petrov, A. Georgieva et al., "Effect of MG132 on proteasome activity and prooxidant/antioxidant status of rat liver subjected to ischemia/reperfusion injury," Hepatology Research, vol. 38, no. 4, pp. 393-401, 2008.

[5] S. Kuboki, T. Okaya, R. Schuster et al., "Hepatocyte NF$\kappa \mathrm{B}$ activation is hepatoprotective during ischemia-reperfusion injury and is augmented by ischemic hypothermia," American Journal of Physiology-Gastrointestinal and Liver Physiology, vol. 292, no. 1, pp. G201-G207, 2007.

[6] J. Vaquero, C. Rose, and R. F. Butterworth, "Keeping cool in acute liver failure: rationale for the use of mild hypothermia," Journal of Hepatology, vol. 43, no. 6, pp. 1067-1077, 2005.

[7] P. Olschewski, P. Gaß, V. Ariyakhagorn et al., "The influence of storage temperature during machine perfusion on preservation quality of marginal donor livers," Cryobiology, vol. 60, no. 3, pp. 337-343, 2010.
[8] A. Ferrigno, F. Carlucci, A. Tabucchi et al., "Different susceptibility of liver grafts from lean and obese Zucker rats to preservation injury," Cryobiology, vol. 59, no. 3, pp. 327-334, 2009.

[9] A. Ferrigno, V. Rizzo, E. Boncompagni et al., "Machine perfusion at $20^{\circ} \mathrm{C}$ reduces preservation damage to livers from nonheart beating donors," Cryobiology, vol. 62, no. 2, pp. 152-158, 2011.

[10] M. Vairetti, A. Ferrigno, F. Carlucci et al., "Subnormothermic machine perfusion protects steatotic livers against preservation injury: a potential for donor pool increase?" Liver Transplantation, vol. 15, no. 1, pp. 20-29, 2009.

[11] J. M. Knaak, V. N. Spetzler, N. Goldaracena et al., "Subnormothermic ex vivo liver perfusion reduces endothelial cell and bile duct injury after donation after cardiac death pig liver transplantation," Liver Transplantation, vol. 20, no. 11, pp. 12961305, 2014.

[12] B. G. Bruinsma, H. Yeh, S. Özer et al., "Subnormothermic machine perfusion for ex vivo preservation and recovery of the human liver for transplantation," American Journal of Transplantation, vol. 14, no. 6, pp. 1400-1409, 2014.

[13] B. G. Bruinsma, J. H. Avruch, P. D. Weeder et al., "Functional human liver preservation and recovery by means of subnormothermic machine perfusion," Journal of Visualized Experiments, no. 98, p. 52777, 2015.

[14] C. D. Deakin, J. P. Nolan, J. Soar et al., "European Resuscitation Council guidelines for resuscitation 2010 section 4. Adult advanced life support," Resuscitation, vol. 81, no. 10, pp. 1305$1352,2010$.

[15] M. Erecinska, M. Thoresen, and I. A. Silver, "Effects of hypothermia on energy metabolism in mammalian central nervous system," Journal of Cerebral Blood Flow \& Metabolism, vol. 23, no. 5, pp. 513-530, 2003.

[16] R. Tissier, M. Chenoune, S. Pons et al., "Mild hypothermia reduces per-ischemic reactive oxygen species production and preserves mitochondrial respiratory complexes," Resuscitation, vol. 84, no. 2, pp. 249-255, 2013.

[17] H. Zhang, J.-J. Zhang, Y.-W. Mei, S.-G. Sun, and E.-T. Tong, "Effects of immediate and delayed mild hypothermia on endogenous antioxidant enzymes and energy metabolites following global cerebral ischemia," Chinese Medical Journal, vol. 124, no. 17, pp. 2764-2766, 2011.

[18] H. Bayr, P. D. Adelson, S. R. Wisniewski et al., "Therapeutic hypothermia preserves antioxidant defenses after severe traumatic brain injury in infants and children," Critical Care Medicine, vol. 37, no. 2, pp. 689-695, 2009.

[19] H. A. Zar, D. Jee, S. Peretta, and R. A. Mueller, "Hypothermia decreases glutathione efflux in the rat liver," in Proceedings of the Anesthesiology Abstracts of Scientific Papers Annual Meeting, Abstract 44, no. 2000, 2002.

[20] H. A. Zar, K. Tanigawa, Y.-M. Kim, and J. R. Lancaster Jr., "Mild therapeutic hypothermia for postischemic vasoconstriction in the perfused rat liver," Anesthesiology, vol. 90, no. 4, pp. 11031111, 1999.

[21] J. Vaquero, M. Bélanger, L. James et al., "Mild hypothermia attenuates liver injury and improves survival in mice with acetaminophen toxicity," Gastroenterology, vol. 132, no. 1, pp. 372-383, 2007.

[22] Q. Qi and P. Bie, "Different roles of hepatic hypothermic ischemia and ischemic preconditioning in chemically induced hepatocarcinogenesis in rats," Journal of Surgical Research, vol. 189, no. 2, pp. 213-221, 2014. 
[23] N. Alva, J. Palomeque, and T. Carbonell, "Oxidative stress and antioxidant activity in hypothermia and rewarming: can RONS modulate the beneficial effects of therapeutic hypothermia?" Oxidative Medicine and Cellular Longevity, vol. 2013, Article ID 957054, 10 pages, 2013.

[24] H. S. Han, J. Park, J.-H. Kim, and K. Suk, "Molecular and cellular pathways as a target of therapeutic hypothermia: pharmacological aspect," Current Neuropharmacology, vol. 10, no. 1, pp. 80-87, 2012.

[25] J. Vaquero, "Therapeutic hypothermia in the management of acute liver failure," Neurochemistry International, vol. 60, no. 7, pp. 723-735, 2012.

[26] T. Jung, B. Catalgol, and T. Grune, “The proteasomal system," Molecular Aspects of Medicine, vol. 30, no. 4, pp. 191-296, 2009.

[27] A. Ciechanover, "Intracellular protein degradation: from a vague idea thru the lysosome and the ubiquitin-proteasome system and onto human diseases and drug targeting," Biochimica et Biophysica Acta-Proteins and Proteomics, vol. 1824, no. 1, pp. 3-13, 2012.

[28] F. Shang and A. Taylor, "Ubiquitin-proteasome pathway and cellular responses to oxidative stress," Free Radical Biology and Medicine, vol. 51, no. 1, pp. 5-16, 2011.

[29] M. Vairetti, P. Richelmi, F. Bertè, R. T. Currin, J. J. Lemasters, and R. Imberti, "Role of $\mathrm{pH}$ in protection by low sodium against hypoxic injury in isolated perfused rat livers," Journal of Hepatology, vol. 44, no. 5, pp. 894-901, 2006.

[30] R. S. Koti, A. M. Seifalian, and B. R. Davidson, "Protection of the liver by ischemic preconditioning: a review of mechanisms and clinical applications," Digestive Surgery, vol. 20, no. 5, pp. 383-396, 2003.

[31] M. Uchiyama and M. Mihara, "Determination of malonaldehyde precursor in tissues by thiobarbituric acid test," Analytical Biochemistry, vol. 86, no. 1, pp. 271-278, 1978.

[32] V. Witko-Sarsat, V. Gausson, A.-T. Nguyen et al., "AOPPinduced activation of human neutrophil and monocyte oxidative metabolism: a potential target for $\mathrm{N}$-acetylcysteine treatment in dialysis patients," Kidney International, vol. 64, no. 1, pp. 82-91, 2003.

[33] S. Aydin, P. Atukeren, U. Çakatay, H. Uzun, and T. Altuğ, "Gender-dependent oxidative variations in liver of aged rats," Biogerontology, vol. 11, no. 3, pp. 335-346, 2010.

[34] M. M. Bradford, "A rapid and sensitive method for the quantitation of microgram quantities of protein utilizing the principle of protein-dye binding," Analytical Biochemistry, vol. 72, no. 1-2, pp. 248-254, 1976.

[35] P. J. Hissin and R. Hilf, "A fluorometric method for determination of oxidized and reduced glutathione in tissues," Analytical Biochemistry, vol. 74, no. 1, pp. 214-226, 1976.

[36] N. Alva, T. Carbonell, and J. Palomeque, "Hypothermic protection in an acute hypoxia model in rats: acid-base and oxidant/antioxidant profiles," Resuscitation, vol. 81, no. 5, pp. 609-616, 2010.

[37] Z. Cui, S. M. Hwang, and A. V. Gomes, "Identification of the immunoproteasome as a novel regulator of skeletal muscle differentiation," Molecular and Cellular Biology, vol. 34, no. 1, pp. 96-109, 2014.

[38] A. Iorga, S. Dewey, R. Partow-Navid, A. V. Gomes, and M. Eghbali, "Pregnancy is associated with decreased cardiac proteasome activity and oxidative stress in mice," PLOS ONE, vol. 7, no. 11, Article ID e48601, 2012.
[39] A. V. Gomes, G. W. Young, Y. J. Wang et al., "Contrasting proteome biology and functional heterogeneity of the $20 \mathrm{~S}$ proteasome complexes in mammalian tissues," Molecular and Cellular Proteomics, vol. 8, no. 2, pp. 302-315, 2009.

[40] Z. Cui, J. E. Gilda, and A. V. Gomes, "Crude and purified proteasome activity assays are affected by type of microplate," Analytical Biochemistry, vol. 446, no. 1, pp. 44-52, 2014.

[41] J. E. Gilda and A. V. Gomes, "Stain-free total protein staining is a superior loading control to $\beta$-actin for Western blots," Analytical Biochemistry, vol. 440, no. 2, pp. 186-188, 2013.

[42] M. Perluigi, R. Coccia, and D. A. Butterfield, "4-Hydroxy-2nonenal, a reactive product of lipid peroxidation, and neurodegenerative diseases: a toxic combination illuminated by redox proteomics studies," Antioxidants \& Redox Signaling, vol. 17, no. 11, pp. 1590-1609, 2012.

[43] N. Alva, D. Azuara, J. Palomeque, and T. Carbonell, "Deep hypothermia protects against acute hypoxia in vivo in rats: a mechanism related to the attenuation of oxidative stress," Experimental Physiology, vol. 98, no. 6, pp. 1115-1124, 2013.

[44] F. Zhang, Y. Hu, P. Huang, C. A. Toleman, A. J. Paterson, and J. E. Kudlow, "Proteasome function is regulated by cyclic AMPdependent protein kinase through phosphorylation of Rpt6," The Journal of Biological Chemistry, vol. 282, no. 31, pp. 2246022471, 2007.

[45] K. H. Polderman, "Application of therapeutic hypothermia in the ICU: opportunities and pitfalls of a promising treatment modality. Part 1: indications and evidence," Intensive Care Medicine, vol. 30, no. 4, pp. 556-575, 2004.

[46] P. J. D. Andrews, H. L. Sinclair, C. G. Battison et al., "European society of intensive care medicine study of therapeutic hypothermia $\left(32-35^{\circ} \mathrm{C}\right)$ for intracranial pressure reduction after traumatic brain injury (the Eurotherm3235Trial)," Trials, vol.12, no. 1, article 8, 2011.

[47] J. W. Lampe and L. B. Becker, "State of the art in therapeutic hypothermia," Annual Review of Medicine, vol. 62, pp. 79-93, 2011.

[48] M. A. Yenari and H. S. Han, "Influence of hypothermia on post-ischemic inflammation: role of nuclear factor $\kappa \mathrm{B}(\mathrm{NF} \kappa \mathrm{B})$," Neurochemistry International, vol. 49, no. 2, pp. 164-169, 2006.

[49] T. Zgavc, D. De Geyter, A.-G. Ceulemans et al., "Mild hypothermia reduces activated caspase- 3 up to 1 week after a focal cerebral ischemia induced by endothelin-1 in rats," Brain Research, vol. 1501, pp. 81-88, 2013.

[50] M. A. Zaouali, I. Ben Mosbah, E. Boncompagni et al., "Hypoxia inducible factor-lalpha accumulation in steatotic liver preservation: role of nitric oxide," World Journal of Gastroenterology, vol. 16, no. 28, pp. 3499-3509, 2010.

[51] H. Jaeschke, "Molecular mechanisms of hepatic ischemiareperfusion injury and preconditioning," American Journal of Physiology-Gastrointestinal and Liver Physiology, vol. 284, no. 1, pp. G15-G26, 2003.

[52] A. Serafín, J. Roselló-Catafau, N. Prats, E. Gelpí, J. Rodés, and C. Peralta, "Ischemic preconditioning affects interleukin release in fatty livers of rats undergoing ischemia/reperfusion," Hepatology, vol. 39, no. 3, pp. 688-698, 2004.

[53] N. Alva, T. Carbonell, and J. Palomeque, "Deep hypothermia impact on acid-base parameters and liver antioxidant status in an in vivo rat model," Canadian Journal of Physiology and Pharmacology, vol. 87, no. 6, pp. 471-478, 2009.

[54] M. Vucetic, A. Stancic, V. Otasevic et al., "The impact of cold acclimation and hibernation on antioxidant defenses in the 
ground squirrel (Spermophilus citellus): an update," Free Radical Biology and Medicine, vol. 65, pp. 916-924, 2013.

[55] P. Venditti, R. De Rosa, M. Portero-Otin, R. Pamplona, and S. Di Meo, "Cold-induced hyperthyroidism produces oxidative damage in rat tissues and increases susceptibility to oxidants," International Journal of Biochemistry and Cell Biology, vol. 36, no. 7, pp. 1319-1331, 2004.

[56] A. Ayala, M. F. Muñoz, and S. Argüelles, "Lipid peroxidation: production, metabolism, and signaling mechanisms of malondialdehyde and 4-hydroxy-2-nonenal," Oxidative Medicine and Cellular Longevity, vol. 2014, Article ID 360438, 31 pages, 2014.

[57] H. Esterbauer, P. Eckl, and A. Ortner, "Possible mutagens derived from lipids and lipid precursors," Mutation Research/Reviews in Genetic Toxicology, vol. 238, no. 3, pp. 223233, 1990.

[58] F. Shang and A. Taylor, "Roles for the ubiquitin-proteasome pathway in protein quality control and signaling in the retina: implications in the pathogenesis of age-related macular degeneration," Molecular Aspects of Medicine, vol. 33, no. 4, pp. 446466, 2012.

[59] T. J. A. Höhn and T. Grune, "The proteasome and the degradation of oxidized proteins: part III-Redox regulation of the proteasomal system," Redox Biology, vol. 2, no. 1, pp. 388-394, 2014.

[60] A. Divald, S. Kivity, P. Wang et al., "Myocardial ischemic preconditioning preserves postischemic function of the $26 \mathrm{~S}$ proteasome through diminished oxidative damage to 195 regulatory particle subunits," Circulation Research, vol. 106, no. 12, pp. 1829-1838, 2010.

[61] Z. Wang, X. Dou, D. Gu et al., “4-Hydroxynonenal differentially regulates adiponectin gene expression and secretion via activating PPAR $\gamma$ and accelerating ubiquitin-proteasome degradation," Molecular and Cellular Endocrinology, vol. 349, no. 2, pp. 222-231, 2012.

[62] D. L. Carbone, J. A. Doorn, and D. R. Petersen, "4Hydroxynonenal regulates $26 \mathrm{~S}$ proteasomal degradation of alcohol dehydrogenase," Free Radical Biology and Medicine, vol. 37, no. 9, pp. 1430-1439, 2004.

[63] K. Okada, C. Wangpoengtrakul, T. Osawa, S. Toyokuni, K. Tanaka, and K. Uchida, "4-hydroxy-2-nonenal-mediated impairment of intracellular proteolysis during oxidative stress: identification of proteasomes as target molecules," The Journal of Biological Chemistry, vol. 274, no. 34, pp. 23787-23793, 1999.

[64] C. Marques, P. Pereira, A. Taylor et al., "Ubiquitin-dependent lysosomal degradation of the HNE-modified proteins in lens epithelial cells," The FASEB Journal, vol. 18, no. 12, pp.1424-1426, 2004.

[65] B. G. Hill, P. Haberzettl, Y. Ahmed, S. Srivastava, and A. Bhatnagar, "Unsaturated lipid peroxidation-derived aldehydes activate autophagy in vascular smooth-muscle cells," Biochemical Journal, vol. 410, no. 3, pp. 525-534, 2008.

[66] H. Malhi, M. E. Guicciardi, and G. J. Gores, "Hepatocyte death: a clear and present danger," Physiological Reviews, vol. 90, no. 3, pp. 1165-1194, 2010.

[67] S. Grimm, L. Ernst, N. Grötzinger et al., "Cathepsin D is one of the major enzymes involved in intracellular degradation of AGE-modified proteins," Free Radical Research, vol. 44, no. 9, pp. 1013-1026, 2010.

[68] E. N. Tsakiri, K. K. Iliaki, A. Höhn et al., "Diet-derived advanced glycation end products or lipofuscin disrupts proteostasis and reduces life span in Drosophila melanogaster," Free Radical Biology and Medicine, vol. 65, pp. 1155-1163, 2013.
[69] A. Hamacher-Brady, N. R. Brady, and R. A. Gottlieb, "Enhancing macroautophagy protects against ischemia/reperfusion injury in cardiac myocytes," The Journal of Biological Chemistry, vol. 281, no. 40, pp. 29776-29787, 2006.

[70] T. Grune and K. J. A. Davies, "The proteasomal system and HNE-modified proteins," Molecular Aspects of Medicine, vol. 24, no. 4-5, pp. 195-204, 2003.

[71] V. Velickovska and F. van Breukelen, "Ubiquitylation of proteins in livers of hibernating golden-mantled ground squirrels, Spermophilus lateralis," Cryobiology, vol. 55, no. 3, pp. 230-235, 2007.

[72] S. N. Djakovic, E. M. Marquez-Lona, S. K. Jakawich et al., "Phosphorylation of Rpt6 regulates synaptic strength in hippocampal neurons," The Journal of Neuroscience, vol. 32, no. 15, pp. 51265131, 2012.

[73] T. J. Jarome, J. L. Kwapis, W. L. Ruenzel, and F. J. Helmstetter, "CaMKII, but not protein kinase A, regulates Rpt6 phosphorylation and proteasome activity during the formation of longterm memories," Frontiers in Behavioral Neuroscience, vol. 7, article 115, 2013.

[74] E. N. Churchill, J. C. Ferreira, P. C. Brum, L. I. Szweda, and D. Mochly-Rosen, "Ischaemic preconditioning improves proteasomal activity and increases the degradation of $\delta \mathrm{PKC}$ during reperfusion," Cardiovascular Research, vol. 85, no. 2, pp. 385-394, 2010.

[75] N. Chondrogianni, I. Petropoulos, C. Franceschi, B. Friguet, and E. S. Gonos, "Fibroblast cultures from healthy centenarians have an active proteasome," Experimental Gerontology, vol. 35, no. 6-7, pp. 721-728, 2000.

[76] V. I. Pérez, R. Buffenstein, V. Masamsetti et al., "Protein stability and resistance to oxidative stress are determinants of longevity in the longest-living rodent, the naked mole-rat," Proceedings of the National Academy of Sciences of the United States of America, vol. 106, no. 9, pp. 3059-3064, 2009. 


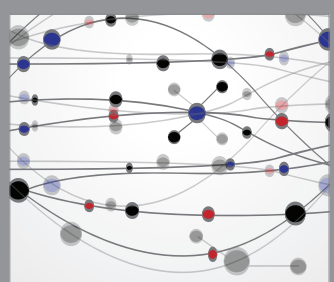

The Scientific World Journal
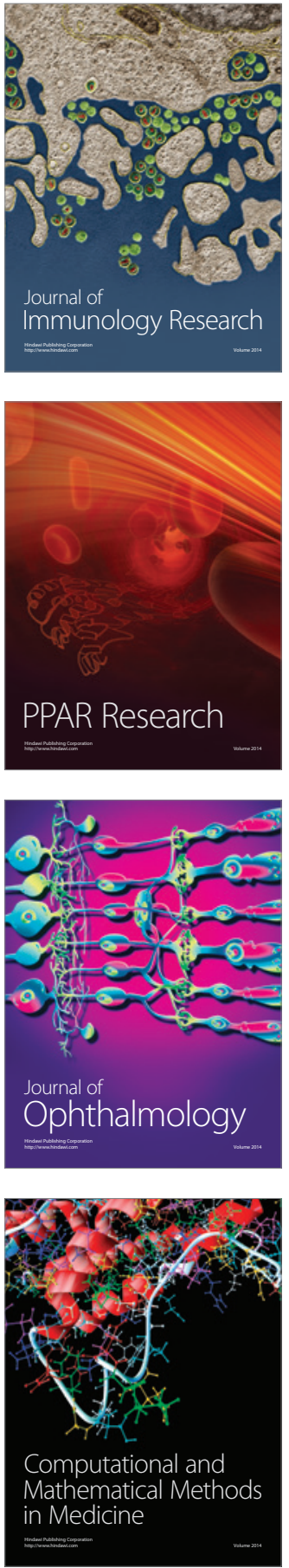

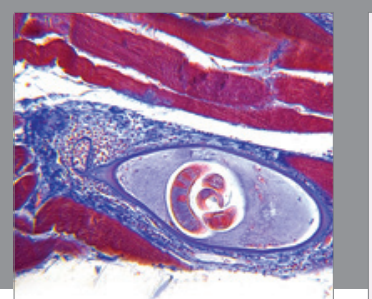

Gastroenterology Research and Practice

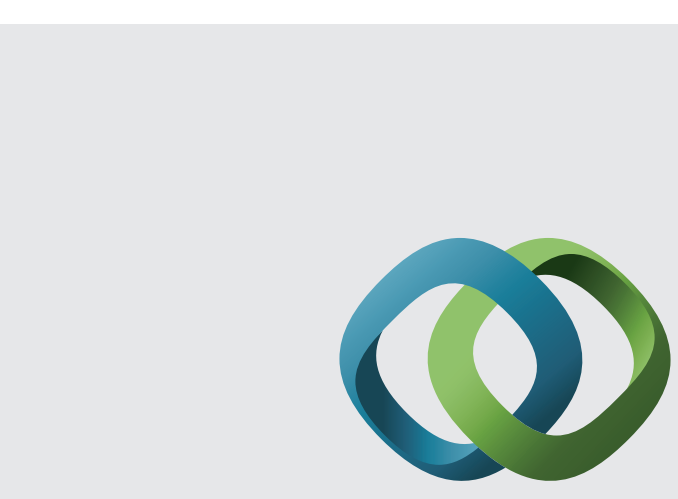

\section{Hindawi}

Submit your manuscripts at

http://www.hindawi.com
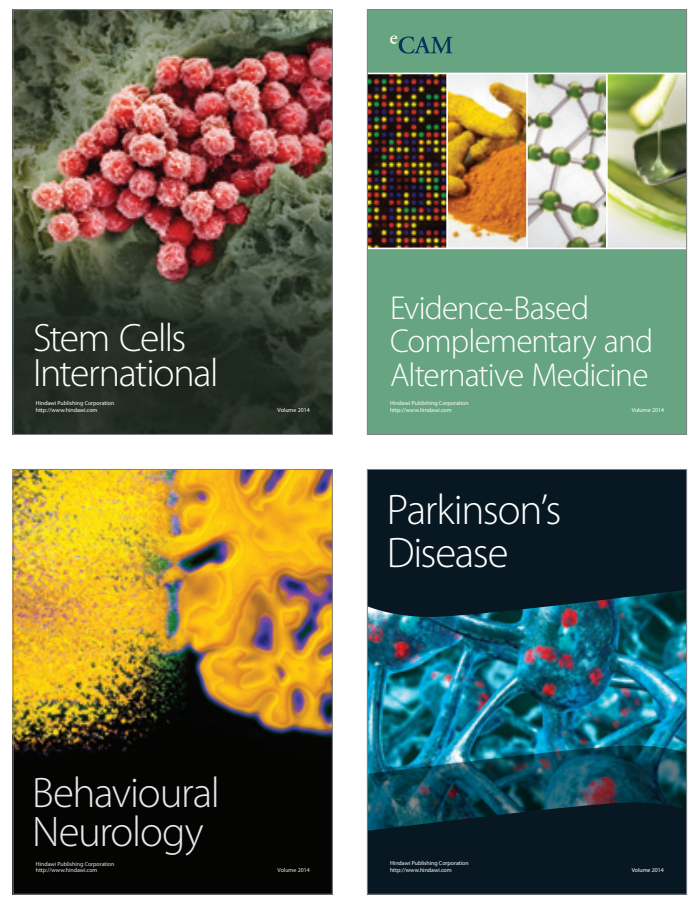
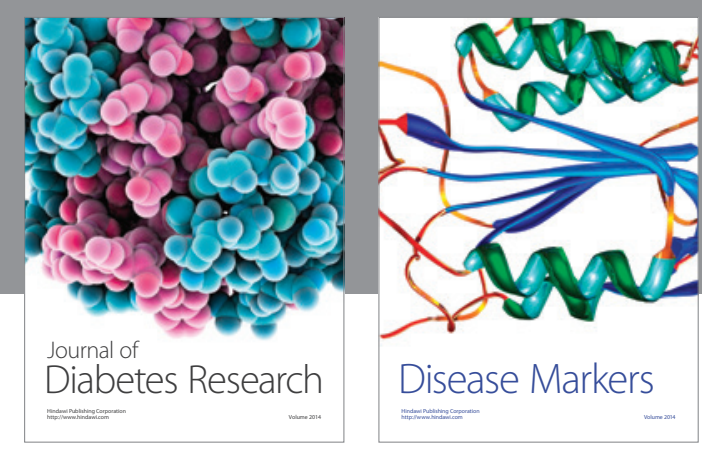

Disease Markers
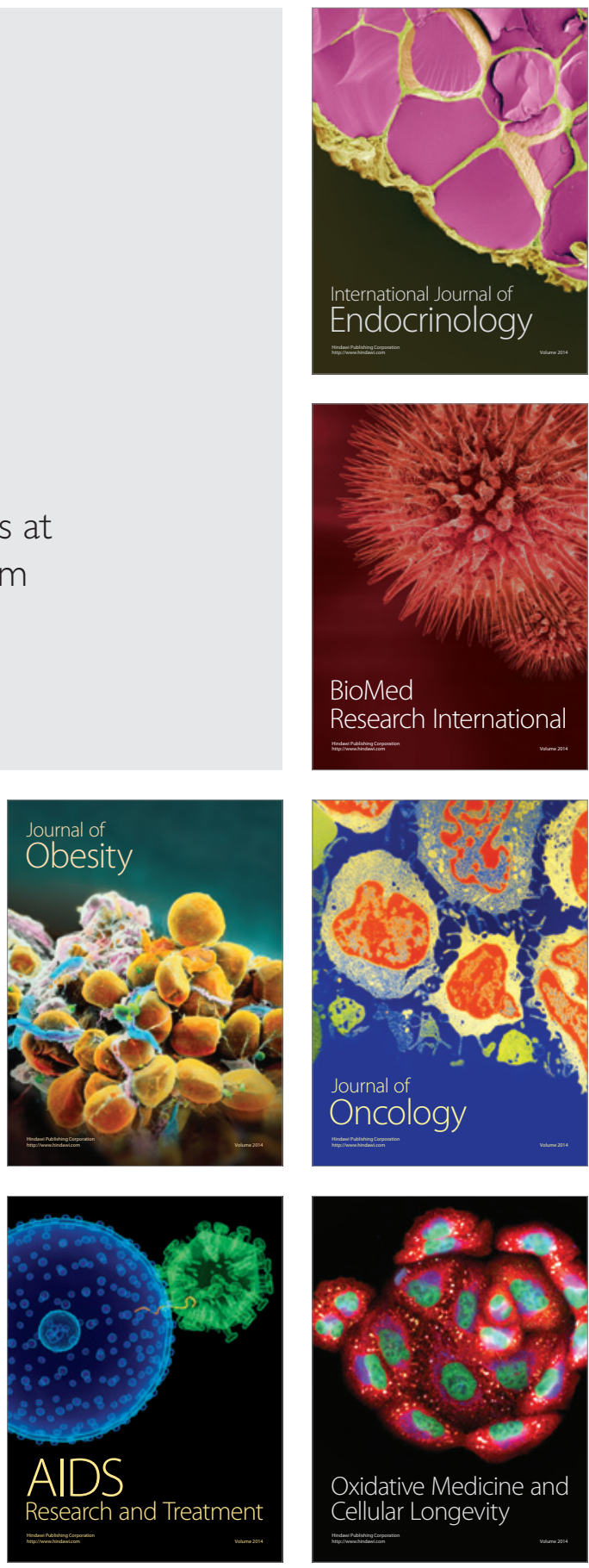